Biljana Kitić ${ }^{1}$, Milica Kostić Stanković ${ }^{\text {, Jelena Cvijović }}{ }^{3}$, Danica Lečić Cvetković

${ }^{1}$ Samardžić, Oreški, Gecić \& Grbović, Kralja Petra 18, Belgrade, Serbia 2, 3, 4 University of Belgrade,Faculty of Organizational Sciences, Serbia

\title{
Environmental Aspect of Business Communications
}

UDC: 005.57 ;

502.13:005.51

DOI: 10.7595/management.fon.2015.0004

SPIN’13, Belgrade, 05-06. November 2013.

In the era of globalization, environmental endangerment and degradation are global in character, so the environmental protection has become a serious problem for civilisation in general. This paper emphasises the efforts being taken by companies to follow environmental changes and position themselves as ecologically responsible through the adoption of a unified business communication policy. The research was conducted on a sample of one hundred employees of the company "AXA Insurance" in order to determine the level of their ecological awareness and pro-environmental behaviour. The findings of the survey indicate that, due to the poor preparedness of Serbian companies to meet environmental requirements and standards applicable in developed countries, environmental awareness of their employees is at a low level. Therefore, this issue should be incorporated in companies' business communication strategies that address both, internal and external target groups.

Keywords: Ecology, environment, business communications, environmental awareness

\section{Introduction}

Mankind is confronted with a series of existential crises today, ecological crises in particular. An ecological crisis can be defined as "any modification of the state of the physical environment due to human activities disrupting such state, with consequences regarded as unacceptable by society, according to adopted environmental standards" (Farmer, 2002, p.54). In the $21^{\text {st }}$ century, society is faced with the following global crises: damage of the biosphere and its ecosystems; overpopulation (more than 6 billion now, forecasted to be doubled by 2020); depletion and reduced quantities of various sources of mineral and energy raw materials; contamination of air, water and soil; global climate changes; extinction of flora and fauna species and the continued endangerment of biodiversity; homelessness (one fourth of the global population); harm to human health and threat to lives; high quantities of waste in all three aggregate conditions, etc. (Cvejić \& Stefanović, 2010). The negative factors affecting environmental contamination in Serbia are: the transfer of "dirty" technologies from the West; underdeveloped technologies that would be more compliant with the principles of environmental policy; low utilization of unconventional sources of energy; underdeveloped innovation management; insufficient application of waste recycling methods; absence of necessary public awareness of the consequences of environmental contamination and so on.

Environmental awareness is fundamental to the continued sustainable development of environmental protection and implies that people should be aware of the characteristics of nature and its potentials, as well as the significance of its preservation for the purpose of their own survival (Wells, 2012). The development of environmental awareness over the years moved from complete absence to formation of various movements tackling this global issue. The creation of an environmental culture arises as a must in overcoming man's consumer attitude towards natural resources. Environmental culture derives from an environmental view of the world based on ecological information and critical valuation of the relation towards the environment.

The protection and improvement of the human environment is a major global problem of today's society. Its resolution initiates, among others, finding of a method for rational and complex use of natural resources, as well as a model for running an active demographic policy and developing and improving international co- 
operation in the field of scientific research. A new attitude towards the environment and its incorporation in present-day business policies is becoming necessary. Scientific approaches to solving this issue vary. Some of them may be (Fraj \& Martinez, 2006):

- Economic systems shifting from permanent growth to steady state;

- Creation of environmental awareness;

- Introduction of social programmes;

- Application of various technological measures (e.g. filters, electric cars, etc.);

- Self-regulating abilities of nature and inventive power of man that will timely detect and properly solve any issue.

\section{The impact of environmental activities on business performance}

In the business context, factors such as the appearance of growing stakeholder activism, easy flow of information, striving towards global competitiveness and necessity of long-term sustainability, make companies switch their goals from profit-based to achieving a positive impact on both internal and external environments (Collierand \& Esteban, 2007). In order to do that, organizations are required to produce more environmental responsibility information and distribute it to all the stakeholders, so they could better understand the impact of overall organization's operations and get involved in some ecological activities (Bakar \& Ameer, 2011). It makes organizations focus their activities towards 3Ps value creation (people, planet, and profit) while communicating with different groups of stakeholders, based on the postulates of transparency and dialogue (Cramer et al., 2004). Setting up environmental standards and legally regulating environmental issues imposed an obligation on organizations to redefine their missions and incorporate environmental principles therein. These principles are based on the following elements (Kostić - Stanković, 2011):

- Creation of an appropriate internal climate and raising employees' awareness;

- Adoption of a single communications policy in respect of environmental issues;

- Adoption of a single strategy for the environmental conservation through continuous communication with the wider community;

- Coordination and cooperation between PR, Marketing and other business functions in solving environmental issues. An organization may be active in such programmes, either through donations and sponsorships or as a strategic initiator, but, no matter what the way of its engagement is, it is necessary that it should communicate with stakeholders about that, by using all business functions (Birch, 2003; Amaladoss \& Manohar, 2013).

Although organizations can have various motives for involvement in environmentally oriented activities (Babiak \& Trendafilova, 2011), these motives are most often classified into two main categories: public-serving and firm-serving. Public-serving motives represent organizational concern for the general, social interest, while firm-serving motives represent concern for benefits that the organization can have from such activities (e.g. improvement of corporate image). (de Vries et al., 2013). In most cases these two motives interfere, so organizations put their focus to fundamentally different, environmentally-driven activities aimed at building up their corporate identity, image and reputation, while doing what is best for the welfare of the society. Environmental care is definitely part of the image and reputation and, among all, constitutes the "good will" value of organizations themselves (Lindridge et al., 2013). In order to really show its good will, an organization needs to base its business on the following postulates (Straughan \& Roberts, 1999): compliance with all legal regulations in the environmental protection; minimizing the environmental contamination (all types of waste, noise, etc.); proper treatment of all hazardous materials and their proper storage and disposal; applying an internal environmental protection programme (recycling, energy saving, etc.). In addition to environmentally responsible business, an organization has a duty to keep its employees informed about continued environmental activities outside the organization and motivate them to get involved into the current environmental protection trends. In the production area, the integration of environmental goals is being promoted in all business aspects - from planning, production strategy definition and production design to interaction with consumers. Therefore, organizations need to find solutions to environmental challenges through modifying and adapting communication strategies, products and services, while keeping competitive attributes. This includes: new technologies for waste treatment and reduction of air pollution; standardization of products in order to ensure their environmental safety; provision of "genuinely" natural products; orientation of products on conservation of natural resources and a greater emphasis on health (Petrović, 2012). By integrating them in business communication strategies, such solutions ensure organizations' contribution to social needs and allow them to position themselves as environmentally responsible. 


\section{Role of business communications in raising environmental awareness}

Organizations must not only integrate environmental behaviour as part of their mission, but they must also communicate this to all stakeholders (Brønn and Vironi, 2001; Ziek, 2009). Stakeholders such as customers, government agencies, non-governmental organizations, employees, investment firms and the general public seek information concerning the organization's policy on environmental issues, social programs and community involvement (Dawkins \& Lewis, 2003). Although communicating environmental issues is still mainly limited to large organizations (Graafland et al., 2003; Knox et al., 2005), a large number of smaller ones are finding their ways to involve themselves. Business communications, observed at the company level, are intended to bring together environmental communication activities performed by an organization in its efforts to adapt to the environmental requirements (Birth et al., 2006). As noted in the existing literature, many channels have been used for this kind of communication - from the annual reports and nonfinancial reporting (Haddock-Fraser \& Fraser, 2008) to corporate web sites (Guimarães-Costa \& Pina e Cunha, 2008). Some of the communication activities that may be performed by an organization, as suggested by Kostić Stanković (2011), are:

- Employee education aimed at raising their environmental awareness through internal communication channels

Using formal and informal channels, through various types of notices, reports, manuals, newsletters, inhouse publications, e-mail, small or large employee meetings or direct communication may have a major effect on employee awareness and behaviour. The Intranet as a network used by all employees for information purposes greatly facilitates the transfer of important information and continually directs employee reactions and thoughts as regards conservation of the environment.

- Raising customer environmental awareness through integrated marketing communications

Even though there is a growing number of customers who consider themselves ecologically educated regarding the types of recyclable packaging or the use of paper bags instead of plastic ones, the majority is, unfortunately, not ready to change established habits yet. Eco-friendly products for many people mean a higher price compared to the standard offer, hence, most customers, regardless of the increased safety of such products and their environmental component, still do not opt for them. In order to influence public perceptions, companies intend to invest in education and motivation of their customers, so they can realise what environmentally responsible purchasing means (Hooghiemstra, 2000). Education is crucial and should be carried out on several levels: during regular schooling; through alternative education; through media and promotional campaigns.

- Integration of environmental groups into target public groups

Globally speaking, the influence and significance of environmental protection advocates is on the rise, and there are various associations and groups in Serbia as well, that are active in this area. Cooperation is possible through different forms of sponsorships and donations which support individuals and groups to follow with their convictions that are in line with the activities promoted by the company.

- Labelling of eco-friendly products

If a company identifies that, within a target group, there is a large number of people who call for conservation of the environment, then this strategy is considered to be justified. Prior to its implementation, research should be conducted on customer environmental commitment, and based on the findings thereof, products and packaging should be labelled as eco-friendly.

- Promotion of eco-friendly products based on environmental protection requirements

This activity is a logical step following implementation of the strategy for labelling eco-friendly products and packaging. After setting the target group requirements for such products, customers need to be informed of the actions taken. Depending on the market itself, i.e. the demand for such products, a company will take appropriate actions, either only to communicate or to educate as well.

- Direct customer communication in line with the environmental protection

Direct communication with customers is based on an integration of social, economic and environmental dimensions in a dialogue on a voluntary basis (Stainer, 2006). This type of communication may be applied on a market with environmentally committed customers in order to fully implement the 3Rs (reduce; recycle; reuse) concept. These three instruments may be applied by reusing recycled material, using packaging which may be used again subsequently and reducing sales costs. 


\section{Research on environmental awareness level}

The main objective of the research conducted towards the end of 2012 on a sample of one hundred employees of the "AXA Insurance" company was to determine the level of environmental knowledge and proenvironmental behaviour. Nearly half of the respondents demonstrated a total lack of information (or had erroneous information) about current environmental issues, which leads to the conclusion that there is still a lack of real interest in this topic. This information is somewhat worrying as the structure of employees sample consisted mainly of people with higher education. The low information level of the employees of AXA Insurance in Serbia might partly be attributed to the absence of personal interest in environmental issues. However, the factor of the business environment which fails to provide sufficient volume of information on this matter and to motivate the involvement in environmental issues should not be eliminated. As many as $90 \%$ of respondents claimed not to have been made properly aware of implemented activities so that poor communication was the cause of their failure to get involved. Owing to such a state of environmental awareness, employees had a passive attitude towards their involvement in decision-making and participating in specific campaigns for solving environmental issues.

Even though the majority of respondents demonstrated a high level of care regarding the existence of environmental infrastructure, a small percentage of them gave this topic priority over current "burning" social issues such as unemployment and a low living standard. Since the solution of environmental issues requires extremely high capital investment, it may be assumed that neither the Government nor non-governmental organisations want to disquiet the public by bringing it to the fore, aware that it is still far from implementation.

The findings show that there was a prominent tendency towards pro-environmental behaviour in case of respondents who were 35 or younger, as they were more conversant with the current environmental issues than their elder co-workers. The majority of respondents understood the significance of education as a major factor in terms of future generations, so they stated that they would actually bring this to the attention of their children and encourage their involvement in environmental activities.

The respondents felt that governmental approach to regulation of pro-environmental behaviour was poorly organized. The research findings showed that employees in Serbia, even working in a company which performed its business on a global level, were considerably less active than their colleagues working for the same company in other countries, as well as that their environmental behaviour itself was insufficiently stimulated. The low participation in environmental activities might be explained by the fact that a small number of environmental campaigns were carried out at a government level, hence the small number of campaigns was carried out internally, by individual organizations.

As it turned out, pro-environmental behaviour, for some respondents, was not a result of knowledge gathered on environmental issues and causes of their occurrence, nor of the critical attitude towards the environmental situation. On the other hand, the percentage of employees who had previously taken part in some environmental campaigns showed that knowledge about environmental issues and their causes, including ways of current situation evaluation, influenced environmentally-oriented behaviour. This means that as knowledge about these issues and their occurrence broadens and more significance is attached thereto, behaviour will be more and more oriented to their mitigation or elimination.

As regards specific activities, the employees were mostly committed to recycling paper and plastic, whereas they felt that they did not have sufficient conditions for recycling other materials (batteries, cartridges and electronic equipment). Nonetheless, when it comes to specific environmental protection campaigns, Serbia is somewhere at the bottom of the list, among undeveloped Third World countries, which is reflected in the fact that merely $3 \%$ of waste is recycled in Serbia, while Austria recycles $97 \%$ of hazardous materials, and Sweden goes so far as to import recyclable materials (Jovanović-Kolomejceva, 2010). The majority of respondents noted that they came to work by car, whereas a small number of them came by bus, merely $2 \%$ by bicycle and no one came on foot. This piece of information evidenced not only employees' habits but also of the habits of Serbian citizens in general.

When it comes to the motivation to take part in future environmental campaigns, the majority of respondents stated that a reward is the best incentive for doing that. By doing so, an individual is given a greater incentive to get involved in solving environmental issues. However, it should be taken into account that em- 
ployees opting for rewards mostly fell in the group of those who had not participated in environmental activities to the day of the survey, or who participated because they had to, although were not overly interested in the matter. The respondents who found motivation in their personal convictions and group efforts mostly belonged to the group of those who had taken part in environmental campaigns and who were satisfied with the effect of such activities.

It is a fact that, over the past few years in Serbia, environmental protection issues have become a more frequent topic of discussion and their significance has been highlighted. However, public discussions are not and cannot be the only way individuals should and can receive this information. The weak influence of educational institutions and non-governmental organizations and poor environmental protection controls are only some of the factors resulting in the absence of a pro-environmental attitude. An environmentally responsible person is formed during childhood, and therefore, given the gravity of the issue, it is necessary to introduce environmental education on all educational levels. The respondents with children older than seven felt that the introduction of such concept into the curriculum would encourage the young to think about this serious topic and that, at the same time, it would shape the values and behaviour in a pro-environmental direction. The environmentally active respondents' children were involved through school groups and informed through the curriculum and lectures on this topic.

Regarding the level of environmental awareness, it was shown that women demonstrated a higher level of environmental awareness (57\%) than men (43\%). Some studies indicated that there was a higher level of knowledge of environmental risks in men, but they demonstrate less care about environmental risks. This claim was based on assumptions that the gender role of women, acquired in the course of socialisation, is linked to a higher degree of care for others and an inclination towards demonstrating empathy and altruism. Another possible explanation is that the differences come from biological, inherent differences between the genders. It could be assumed that women are more sensitive than men, and, owing to the maternal instinct, they have a natural predisposition to show more care for the environment as well (Laroche et al., 2001). Integration of these two theories results in a comprehensive explanation that the differences in valuing the environmental situation are the consequence of interaction between the inherent and acquired traits of women and men through socialisation.

Based on the foregoing, it can be concluded that social factors play a major role in creating and directing an environmentally desirable behaviour. The low level of information on environmental issues, as well as the low level of valuation of environmental issues, are the consequences of poor efforts invested by society and companies in educating the population, i.e., employees, regarding this topic. As the most efficient channels of environmental communication, the largest number of respondents stated press, the Internet and television.

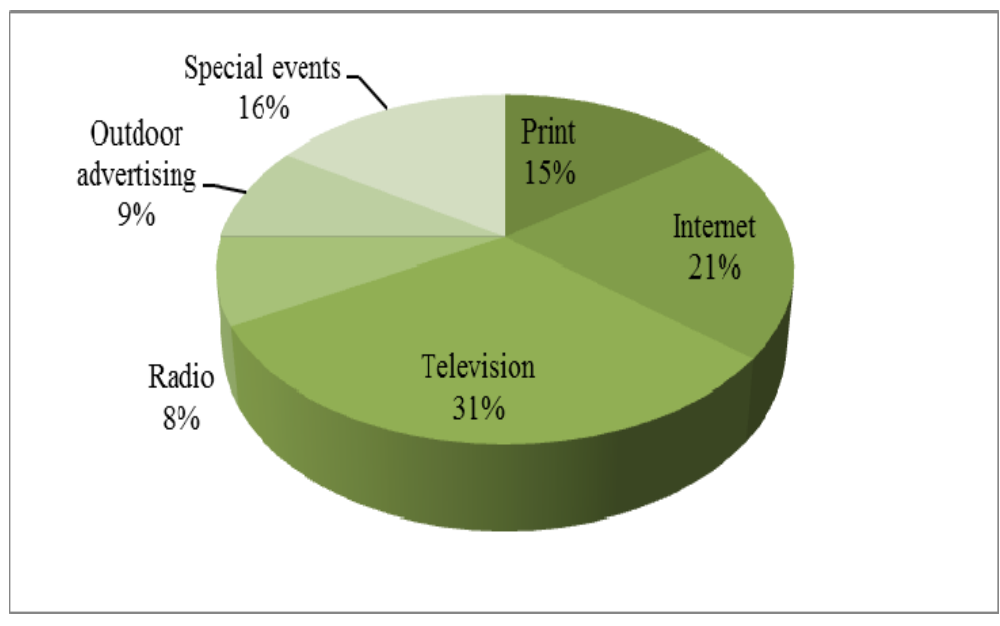

Figure 1: Share of channels used for environmental communication 
Employees saw the Intranet as a very efficient means of communication as they have already developed the habit of using it. The Intranet allows efficient communication and exchange of information on specific job issues, as well as on actual or future environmental campaigns. The respondents emphasised informal communication as very desirable regarding this topic, which can be explained by the absence of pressure from their superiors and by an opportunity to exchange experience.

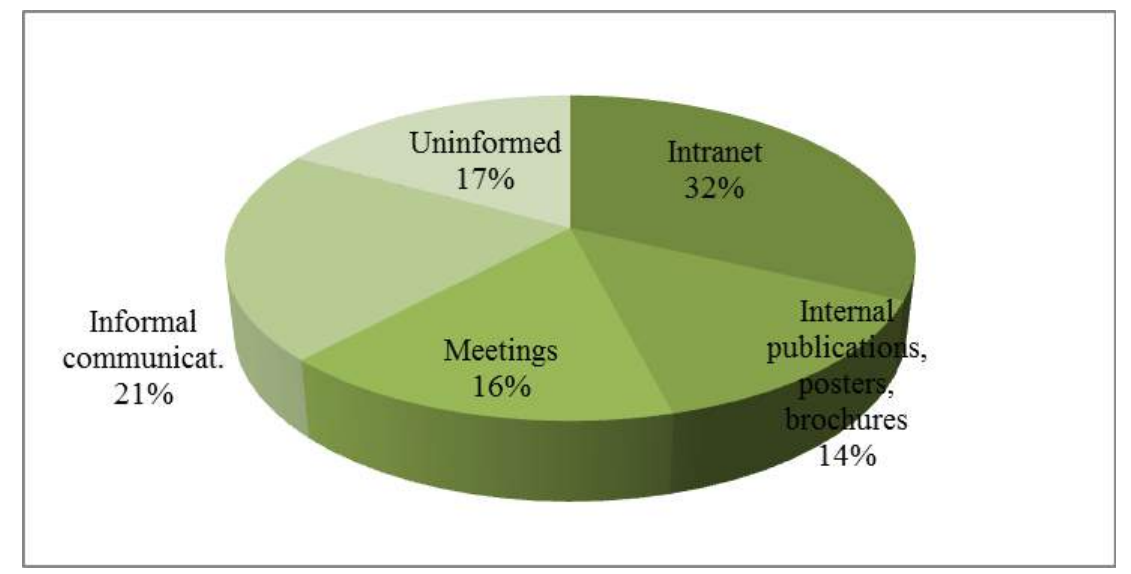

Figure 2: Channels of internal environmental communication in AXA Insurance

\section{Conclusion}

Based on the findings of the survey, it can be concluded that, due to the fact that organizations are not nearly sufficiently prepared to meet requirements, norms and standards applicable on the markets of developed countries, as well as due to their their lagging behind the scientific, technological and industrial developments, environmental awareness of employees in Serbia is at a very low level. In addition to enacting and enforcing laws in this field, it is necessary that continual environmental communication programmes should be implemented on all levels and encourage all stakeholders to take part in environmental protection oriented activities, aimed at establishing a balance between short-term benefits of individual stakeholders and long-term benefits for the society as a whole.

\section{REFERENCES}

[1] Amaladoss, M.X., \& Manohar, H.L. (2013). Communicating corporate social responsibility - A case of CSR communication in emerging economies. Corporate Social Responsibility and Environmental Management, 20, 65-80.

[2] Babiak, K., \& Trendafilova, S. (2011). CSR and environmental responsibility: Motives and pressures to adopt green management practices. Corporate Social Responsibility and Environmental Management, $18,11-24$.

[3] Bakar, A.S.A., \& Ameer, R. (2011). Readability of corporate social responsibility communication in Malaysia. Corporate Social Responsibility and Environmental Management, 18, 50-60.

[4] Birth, G., Illia, L., Lurati, F., \& Zamparini, A. (2006). Communicating CSR: The practice in the top 300 companies in Switzerland. $10^{\text {th }}$ International Conference on Corporate Reputation, Identity and Competitiveness, Zurich.

[5] Brønn, P.S., \& Vrioni, A.B. (2001). Corporate social responsibility and cause related marketing: an overview. International Journal of Advertising, 20, 207-222.

[6] Collierand, J., \& Esteban, R. (2007). Corporate social responsibility and employee commitment. Business Ethics: A European Review, 161, 19-33.

[7] Cramer, J., Heijden, A.V.D., \& Jonker, J. (2004). Corporate social responsibility: Balancing between thinking and acting. International Centre for Corporate Social Responsibility, ICCSR Research Paper Series, No. 28. 
[8] Cvejić, R., \& Stefanović, S. (2010). Ecological management. Belgrade: Higher Education Institution for Applied Studies of Entrepreneurship.

[9] Dawkins, J., \& Lewis, S. (2003). CSR in stakeholder expectations: and their implication for company strategy. Journal of Business Ethics, 44, 185-193.

[10] de Vries, G., Terwel, B.W., Ellemers, N., \& Daamen, D.D.L. (2013). Sustainability or profitability? How communicated motives for environmental policy affect public perceptions of corporate greenwashing. Corporate Social Responsibility and Environmental Management, 5, 15-28.

[11] Farmer, J. D. (2002). Market force, ecology and evolution. Industrial and Corporate Change, 11(5), 895953.

[12] Fraj, E., \& Martinez, E. (2006). Environmental values and lifestyles as determining factors of ecological consumer behaviour: An empirical analysis. Journal of Consumer Marketing, 23(3), 133-144.

[13] Graafland, J., van de Ven., \& Nelleke, S. (2003). Strategies and instruments for organising CSR by small and large businesses in the Netherlands. Journal of Business Ethics, 47, 45-60.

[14] Guimarães-Costa, N., \& Pina e Cunha, M. (2008). The atrium effect of website openness on the communication of corporate social responsibility. Corporate Social Responsibility and Environmental Management, 15, 43-51.

[15] Haddock-Fraser. J, \& Fraser, I. (2008). Assessing corporate environment reporting motivations: differences between 'close-to-market' and 'business-to-business' companies. Corporate Social Responsibility and Environmental Management, 15, 140-155.

[16] Hooghiemstra, R. (2000). Corporate communication and impression management - new perspectives why companies engage in corporate social reporting. Journal of Business Ethics, 27, 55-68.

[17] Jovanović - Kolomejceva, L. (2010). Ecological management, Belgrade: Academia Printing house.

[18] Knox, S., Maklan, S., French, P. (2005). Corporate social responsibility: Exploring stakeholder relationships and programmed reporting across leading FTSE companies. Journal of Business Ethics, 61, 728.

[19] Kostić-Stanković, M. (2011). Integated business communications. Belgrade: Faculty of Organizational Sciences.

[20] Laroche, M., Bergeron, J., \& Barbaro - Forleo, G. (2001).Targeting consumers who are willing to pay more for environmentally friendly products. Journal of Consumer Marketing, 18(6), 503-520.

[21] Lindridge, A., MacGaskill, S., Ginch, W., \& Eadie, D. (2013). Applying an ecological model to social marketing communications. The European Journal of Marketing, 45(2), 152-164.

[22] Petrović, N. (2012). Ecological management. Beograd: Faculty of Organizational Sciences.

[23] Stainer, L. (2006). Performance management and corporate social responsibility: The strategic connection. Strategic Change, 155, 253-264.

[24] Straughan, D. R., \& Roberts, J. A. (1999). Environmental segmentation alternatives: A look at green consumer behaviour in the new millennium. Journal of Consumer Marketing, 16(6), 558-575.

[25] Ziek, P. (2009). Making sense of CSR communication. Corporate Social Responsibility and Environmental Management, 16, 137-145.

[26] Wells, V. K. (2012). Foraging: An ecology model of consumer behaviour? Marketing Theory, 12(2), 117-136 


\section{$1 / 1 / 1 / 1 / 1 / 1 / 1 / 1 / 1 / 1 / 1 / 1 / 1 / 1 / 1 /$ abouthe eathor}

\section{Biljana Kitić \\ Samardžić, Oreški, Gecić \& Grbović Law Firm beeljana@yahoo.com}

Biljana Kitić works as a Business Development Manager at the law firm Samardžić, Oreški, Gecić \& Grbović. She received her MSc degree in Multimedia communications and public relations at the Faculty of Organizational Sciences, University of Belgrade in

2013. She focuses her career on the area of business development, brand management, corporate communications and practice-specific media presentations.

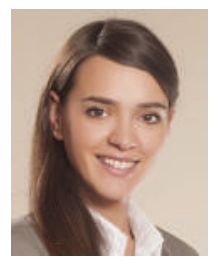

\section{Milica Kostić - Stanković \\ Faculty of Organizational Sciences, University of Belgrade milica@fon.rs}

Milica Kostić - Stanković works as a Full professor in the scientific field of Marketing management, public relations and multimedia communications at the Faculty of Organizational Sciences, University of Belgrade. She is also engaged in organizing and developing the curriculum and teaching at the Faculty of Civil Engineering, University of Belgrade, as well as at the University of Business Engineering and Management and the

Faculty of Political Sciences, University of Banja Luka in Bosnia and Herzegovina.

\section{Jelena Cvijović \\ Faculty of Organizational Sciences, University of Belgrade jelencvijovic85@gmail.com}

Jelena Cvijović is a doctoral student at the Faculty of Organizational Sciences, University of Belgrade. The areas of her scientific interest are: marketing communications, indirect advertising, social marketing and consumer behaviour. She has so far published twenty research papers in international and national journals and

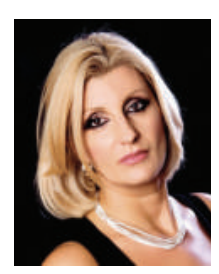
conference proceedings.

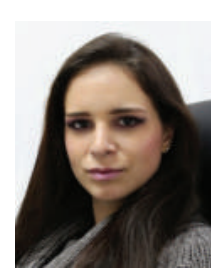

Danica Lečić-Cvetković Faculty of Organizational Sciences, University of Belgrade danica@fon.bg.ac.rs

Danica Lečić-Cvetković is associate professor of Production and services management and e-manufacturing at the Department for Operations management, at the Faculty of Organizational Sciences, University of Belgrade. Her research interests and fields are related to Operations management, Production and services management, e-

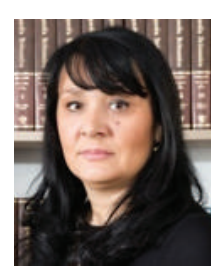
manufacture. So far she has authored more than 70 papers in journals and conference proceedings, published in international and national journals and conferences. 